\title{
MENTAL ACCOUNTING DAN DAMPAKNYA TERHADAP KINERJA PERUSAHAAN MELALUI PENEMPATAN MODAL KERJA PADA USAHA KECIL DAN MENENGAH DI PULAU LOMBOK
}

\author{
Siti Aisyah Hidayati*) \\ Sri Wahyulina*) \\ Laila Wardani*) \\ Iwan Kusuma Negara*)
}

\begin{abstract}
This study aims at analyzing: 1) the effect of mental accounting on placement of funds for working capital in small-and middle-scale business, 2) the effect of placement of funds for working capital on company performance in small-and middle-scale business, and 3) the effect of mental accounting on company performance through placement of funds for working capital in small-and middle-scale business.

The population of this study was all the small- and middle-scale businesses in Lombok Island. Samples were collected by using judgment sampling of non probability sampling. The samples taken were the small-and middle-scale businesses of pottery industry which have exported their goods. The respondents were the managers and owners of small- and middle-scale businesses. The method of data analysis employed in this study was Generalized Structured Component Analysis.

The finding of this study showed that mental accounting is rational by nature and have significant effects on company performance through placement of funds for working capital in small-and middle-scale business. This phenomenon is grounded from the fact that most managers and owners of those small-and middle-scale businesses are men who are on their productive age, and have more than 10 years of experience. The placement of funds for working capital is shown by the efficiency of cash, receivable and inventory management which in turn improve the company performance.
\end{abstract}

Keywords: mental accounting, working capital, company performance

\section{PENDAHULUAN}

Ilmu keuangan berpijak pada asumsi rasionalitas, dimana para pelakunya akan bertindak rasional dan mampu mengoptimalkan cognitive ability untuk membuat keputusan keuangan yang tepat sasaran (ekonomi.kompasiana.com, 15 Maret 2012). Adanya aspek rasionalitas dalam pengambilan keputusan pada saat dihadapkan pada unsur ketidakpastian, yang terkait dengan ekonomi dan portfolio keuangan, manusia akan mengedepankan akal dan nalarnya. Namun demikian, karena manusia diyakini selalu tidak bisa lepas dari aspek bias pada saat proses pengambilan keputusan menyebabkan pembuat keputusan keuangan (decision maker) mengalami kekeliruan (error).

Mental Accounting merupakan salah satu aspek dalam behavioural finance yang sering dialami oleh pengambil keputusan. Hal ini merujuk pada kecenderungan pemilik usaha untuk mengelompokkan keuangan mereka pada rekening yang berbeda-beda didasarkan pada kriteria kriteria yang subjektif, seperti sumber pendanaan dan maksud pemanfaatan penghasilan. Secara teknik, Mental Accounting dilakukan dengan cara pengkodean, pengkategorisasian dan evaluasi terhadap keputusan keuangan (Pompian, 2006:171). Dalam penelitian, mental accounting dapat ditunjukkan oleh penilaian yang berbeda yang diberikan oleh seseorang terhadap dua macam keuntungan moneter yang sejenis karena dikodekan dan dievaluasi melalui mental account yang berbeda (Prakoso, 2009). Penentuan pilihan yang diambil seringkali mencerminkan sikap yang tidak

\footnotetext{
*Staf Pengajar Jurusan Manajemen FEB UNRAM dan MM UNRAM
} 
rasional dari pengambil keputusan. Konsep mental accounting membingkai pilihan keputusan investasi dalam potensi keuntungan dan kerugian (portfolio).

Usaha Kecil dan Menengah (UKM) di Pulau Lombok masih dihadapkan dengan permasalahan mentalitas dalam pengambilan keputusan oleh manajer sekaligus pemilik UKM terutama yang berkaitan dengan pengelolaan keuangan. Berbagai faktor kelemahan internal yang mempengaruhi kinerja dan keberhasilan atau kegagalan Usaha Kecil dan Menengah diantaranya ketidakmampuan di dalam manajemen, lemahnya kemampuan dalam pengambilan keputusan, kurang pengalaman, lemahnya pengawasan keuangan, serta skala usaha yang terlalu kecil (Idrus, 1999:18). Selain itu, ada satu hal yang sering terabaikan adalah Mentalitas Pengusaha UKM (Dinas Koperasi Padang, 2009). Hal ini berkaitan dengan behavioural financial terutama mental accounting. Penyebabnya adalah kepemilikan UKM didominasi oleh perorangan, sehingga pertimbangan-pertimbangan dalam pengambilan keputusan yang dilakukan banyak berdasarkan intuisi yang dimiliki oleh manajer UKM yang sekaligus sebagai pemiliknya.

Keputusan investasi dalam modal kerja pada UKM merupakan hal yang penting, karena UKM mempunyai akses yang terbatas pada modal yang bersifat jangka panjang (Weston dan Copeland, 1986:277). Keputusan investasi pada UKM pada penelitian ini terkait dengan bagaimana pengusaha UKM menempatkan dananya pada modal kerja yaitu aktiva lancar yang terdiri dari kas, piutang dan persediaan. Keputusan investasi akan mempengaruhi kinerja keuangan suatu perusahaan dapat dilihat pada penelitian yang dilakukan oleh Caballero, Teruel dan Solano (2011) yang menyatakan bahwa ada hubungan yang kuat antara investasi pada modal kerja dengan kinerja perusahaan. Menurut penelitian tersebut, walaupun terbatasnya pengujian terhadap investasi modal kerja dihubungkan dengan nilai perusahaan, ide tentang pengaruh manajemen modal kerja terhadap nilai perusahaan dapat diterima secara umum.

\section{Penelitian ini bertujuan untuk:}

\section{TUJUAN PENELITIAN}

1. Menganalisis pengaruh mental accounting terhadap penempatan modal kerja pada UKM di Pulau Lombok.

2. Menganalisis pengaruh penempatan dana untuk modal kerja terhadap kinerja perusahaan di Pulau Lombok.

3. Menganalisis pengaruh mental accounting terhadap kinerja perusahaan melalui penempatan dana untuk modal kerja pada UKM di Pulau Lombok.

\section{TINJAUAN PUSTAKA DAN HIPOTESIS}

\subsection{TINJAUAN PUSTAKA}

\subsubsection{Pengertian Behavioural Finance}

Menurut De Bondt, et al. (2008:7) menyatakan "Behavioral finance is the study of how psychology impacts financial decisions in households, market and organizations", yang artinya studi tentang bagaimana psikologi berdampak pada keputusan-keputusan keuangan di dalam rumah tangga, pasar dan organisasi. Sedangkan menurut Pompian (2006:4) Behavioral Finance, commonly defined as the application of psychology to finance. Shefrin's (2005) dalam Forbes (2009:1) Behavioral finance is the study of how 
psychological phenomena impact financial behavior. Sedangkan menurut Lintner (1998:7), behavioural finance "the study of humans interpret and act on information to make informed investment decisions" artinya, keuangan perilaku merupakan ilmu yang mempelajari bagaimana manusia menginterpretasikan dan bertindak terhadap informasi untuk membuat keputusan dalam berinvestasi. Jadi unsur sikap dan tindakan manusia merupakan faktor penentu dalam berinvestasi. Sehingga Behavioural finance, secara sederhana dapat didefinisikan sebagai aplikasi dari psikologi ke dalam disiplin ilmu keuangan dalam pengambilan keputusan keuangan di dalam rumah tangga, pasar dan organisasi.

Ricciardi dan Simon (2000) dalam Gumanti (2009:8) membagi tiga kelompok individu yang memiliki kepentingan baik secara langsung/tidak langsung terhadap behavioural finance:

1. Individual, yang terdiri dari small investor, portfolio manager, pension board

2. Group, yang terdiri dari investor reksadana (portfolio)

3. Organization, misalnya financial institution, non - profit organization

Isu sentral yang ditelaah oleh behavioural finance mencakup pertanyaan " mengapa investor dan manajer keuangan melakukan kesalahan sistematis dalam mengambil keputusan investasi ?". Selain itu behavioural finance juga menjelaskan perilaku beberapa pihak dan pelaku pasar yang mengambil keuntungan dari ketidakefisienan pasar melalui perilaku arbitrage. Behavioural finance juga menitikberatkan pada beberapa bentuk ketidakefisienan pasar. Reaksi yang keliru dari para pelaku pasar disebabkan oleh kesalahan penilaian, overconfidence/ overoptimism dan berbagai kesalahan lainnya yang ditimbulkan oleh psychological bias.

\subsubsection{Teori-teori Behavioural Finance}

Ricciardi dan Simon (2000) dalam Gumanti, (2009:9) membagi empat tema utama yang tercakup dalam keuangan perilaku.

\section{a. Overconfidence Theory}

Keyakinan berlebihan sudah menjadi salah satu topik menarik yang mendapatkan perhatian luas dari para peneliti dibidang psikologis dan keuangan perilaku. Sebagai manusia, tidak dapat disangkal bahwa pengusaha atau manajer memiliki kecenderungan untuk terlalu yakin atas kemampuan dan prediksi untuk berhasil. Kondisi ini merupakan hal yang normal yang sekaligus merupakan cermin dari tingkat keyakinan seseorang untuk mencapai atau mendapatkan sesuatu. Keyakinan yang berlebihan juga muncul dari sudut pandang bidang pemasaran.

b. Financial Cognitive Dissonance Theory

Teori ketidakberaturan kognitif keuangan (financial cognitive dissonance) yang dikembangkan oleh Festinger dalam Morton (1993) dalam Gumanti (2009:10), menyatakan bahwa manusia merasakan tekanan internal dan keraguan atau ketakutan manakala dihadapkan pada benturan atau perbedaan keyakinan. Sebagai individu, sebaiknya mencoba untuk mengurangi konflik internal yang ada pada diri (mengurangi dissonance) setidaknya dengan satu dari dua cara berikut, yaitu (1) merubah nilai masa lalu, perasaan atau opini, dan (2) mencoba untuk merasionalisasi pilihan-pilihan.

\section{c. Regret Theory}

Teori penyesalan (regret theory) menyatakan bahwa individual melakukan evaluasi reaksi harapan pada suatu kejadian atau situasi di masa depan. Bell (1982) menggambarkan penyesalan (regret) sebagai emosi yang disebabkan oleh perbandingan pada suatu keluaran tertentu (a given outcome) atau suatu kejadian dengan sesuatu yang tidak jadi dipilih (foregone choice).

\section{d. Prospect Theory}

Teori prospek (prospect theory) berkaitan dengan ide bahwa manusia tidak selalu berperilaku secara rasional. Teori ini beranggapan bahwa ada bias yang melekat dan terus ada yang dimotivasi oleh faktor-faktor psikologi yang mempengaruhi pilihan orang dibawah kondisi ketidakpastian. Teori prospek mempertimbangkan preferensi sebagai suatu fungsi timbangan-timbangan keputusan dan berasumsi bahwa timbangan-timbangan keputusan dan berasumsi bahwa timbangan-timbangan 
tersebut tidak selalu tepat dengan probabilitas. Secara spesifik, teori prospek berpendapat bahwa timbangan-timbangan cenderung lebih tinggi daripada probabilitas yang rendah dan lebih rendah daripada probabilitas yang moderat atau tinggi

\subsection{HIPOTESIS}

H1 : Mental accounting berpengaruh terhadap penempatan modal kerja pada UKM di Pulau Lombok.

H2 : Penempatan dana untuk modal kerja berpengaruh terhadap kinerja perusahaan di Pulau Lombok.

H3 : Mental accounting berpengaruh terhadap kinerja perusahaan melalui penempatan dana untuk modal kerja pada UKM di Pulau Lombok

\subsection{Pendekatan Penelitian}

\section{METODE PENELITIAN}

Penelitian ini merupakan penelitian berbasis pendekatan kuantitatif, dengan jenis penelitian explanatory research yang menganalisis pengaruh satu variabel terhadap variabel lainnya. Penelitian ini menganalisis mental accounting terhadap kinerja perusahaan melalui keputusan penempatan dana untuk modal kerja pada UKM di Pulau Lombok.

\subsection{Lokasi Penelitian}

Penelitian ini dilakukan pada UKM gerabah yang melakukan ekspor di Pulau Lombok.

\subsection{Populasi Penelitian}

Populasi penelitian adalah semua UKM di Pulau Lombok yang berjumlah 64.455 unit (Dinas Perindustrian dan Perdagangan Prov. NTB, 2015).

\subsection{Teknik Pengambilan sampel}

Teknik pengambilan sampel dilakukan dengan non probability sampling, yaitu menggunakan judgment sampling yaitu memilih sampel dengan pertimbangan tertentu. Sampel yang diambil adalah UKM yang bergerak pada industri kerajinan gerabah dan sudah melakukan ekspor. Hal ini berdasarkan pada pertimbangan bahwa UKM tersebut mempunyai konsep mental accounting yang membingkai pilihan keputusan investasi dalam potensi keuntungan dan kerugian (portfolio). Sampel yang dapat diambil dari populasi yang ada adalah 29 UKM yang berada di Pulau Lombok.

\subsection{Unit Analisis}

Unit analisis penelitian adalah UKM yang bergerak pada usaha gerabah dan sudah melakukan ekspor berjumlah sebanyak 29 UKM yang berada di Pulau Lombok. Responden dalam penelitian ini adalah manajer yang sekaligus pemilik dari tiap-tiap UKM tersebut.

\subsection{Variabel Penelitian}

Penelitian ini menggunakan dua jenis variabel, yaitu variabel eksogen dan variabel endogen.

1. Variabel eksogen yaitu mental accounting.

2. Variabel endogen penelitian ini adalah penempatan dana untuk modal kerja dan kinerja perusahaan.

\subsection{Definisi Operasional Variabel}

4.7.2. Variabel Eksogen

\subsubsection{Mental Accounting}

Mental accounting adalah perlakuan manajer dalam mengelola kegiatan keuangan yang berkaitan dengan kas, piutang dan persediaan. Indikator yang digunakan bersifat refleksif. Adapun indikator dan itemnya ditunjukkan dalam Tabel 1.

Tabel 1. Indikator dan Item Variabel Mental Accounting 


\begin{tabular}{|c|c|c|}
\hline No. & Indikator & Item \\
\hline 1. & $\begin{array}{l}\text { Kas: uang yang tersedia (termasuk tabungan) yang dapat } \\
\text { dipergunakan apabila diperlukan. }\end{array}$ & $\begin{array}{ll}\text { 1. } & \text { Pemilik UKM selalu } \\
\text { menghitung kebutuhan kas } \\
\text { pada periode yang akan } \\
\text { datang berdasarkan target } \\
\text { yang telah ditetapkan } \\
\text { sebelumnya } \\
\text { 2. Pemilik UKM selalu } \\
\text { membuat laporan kas masuk } \\
\text { dan kas keluar }\end{array}$ \\
\hline 2. & Piutang: Penjualan produk secara kredit & $\begin{array}{l}\text { 1. Pemilik UKM selalu } \\
\text { membuat daftar penagihan } \\
\text { piutang } \\
\text { 2. Pemilik UKM selalu } \\
\text { membuat laporan piutang }\end{array}$ \\
\hline 3. & $\begin{array}{l}\text { Persediaan: Produk yang dihasilkan dan tersedia di } \\
\text { showroom }\end{array}$ & 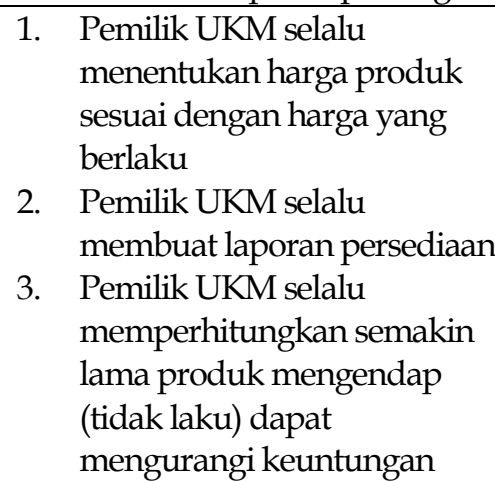 \\
\hline
\end{tabular}

\subsubsection{Variabel Endogen}

\subsubsection{Penempatan Dana untuk Modal Kerja}

Penempatan dana untuk modal kerja diukur dengan menggunakan indikator-indikator yang bersifat refleksif. Adapun indikator dan itemnya ditunjukkan dalam Tabel 2.

Tabel 2.Indikator dan Item Variabel Penempatan Dana untuk Modal Kerja

\begin{tabular}{|c|c|c|}
\hline No. & Indikator & Item \\
\hline 1. & Efficiency of Cash Management (ECM) & $\begin{array}{ll}\text { 1. } & \text { Persiapan anggaran kas } \\
\text { 2. } & \text { Penentuan saldo kas yang ingin dicapai } \\
\text { 3. } & \text { Penghitungan jumlah kas yang seharusnya } \\
\text { tersedia }\end{array}$ \\
\hline 2. & Efficiency of Receivables Management (ERM) & $\begin{array}{l}\text { 1. Persiapan pedoman kredit untuk pelanggan } \\
\text { 2. Memeriksa tingkat piutang } \\
\text { 3. Memeriksa tingkat kredit macet }\end{array}$ \\
\hline 3. & Efficiency of Inventory Management (EIM) & $\begin{array}{ll}\text { 1. } & \text { Persiapan anggaran persediaan } \\
\text { 2. } & \text { Memeriksa tingkat persediaan } \\
\text { 3. } & \text { Mengantisipasi ketidaktepatan jumlah persediaan }\end{array}$ \\
\hline
\end{tabular}




\subsubsection{Kinerja Perusahaan}

Kinerja perusahaan merupakan tolok ukur keberhasilan perusahaan, yang meliputi indikator financial dan indikator non financial. Indikator-indikator kinerja perusahaan UKM bersifat formatif. Adapun indikator dan itemnya ditunjukkan dalam Tabel 3.

Tabel 3. Indikator dan Item Variabel Kinerja Perusahaan

\begin{tabular}{|c|c|c|}
\hline No. & Indikator & Item \\
\hline 1. & Kinerja Financial & $\begin{array}{l}\text { 1. Rasio Keuntungan bersih terhadap investasi } \\
\text { 2. Rasio keuntungan bersih terhadap penjualan } \\
\text { 3. Pertumbuhan Penjualan }\end{array}$ \\
\hline 2. & Kinerja Non Financial & $\begin{array}{l}\text { 1. Pengembangan produk baru } \\
\text { 2. Peningkatan pasar } \\
\text { 3. Pengembangan sumberdaya manusia }\end{array}$ \\
\hline
\end{tabular}

\subsection{Pengukuran Variabel}

4.8.1. Pengukuran Variabel eksogen

Skala Likert digunakan untuk mengukur variabel eksogen, yaitu Mental Accounting. Variabel yang akan diukur dijabarkan menjadi indikator. Hubungan antar variabel tersebut di atas dirumuskan dalam hipotesis penelitian yang akan diuji kebenarannya. Dengan kata lain penelitian ini bertujuan untuk menguji hipotesis. Pengukuran variabel ini dilakukan dengan skala Likert yang dituangkan dalam bentuk pilihan jawaban angket, yaitu: a. Sangat tidak setuju (skor 1); b. Tidak Setuju (skor 2); c. Netral (Skor 3); d. Setuju (skor 4); e. Sangat setuju (skor 5).

\subsubsection{Pengukuran Variabel Endogen}

4.8.2.1. Untuk mengukur variabel penempatan dana untuk modal kerja

Pengukuran variabel penempatan dana untuk modal kerja dilakukan dengan skala Likert. Adapun skor skala yang digunakan adalah: a. Sangat tidak setuju (skor 1); b. Tidak setuju (skor 2); c. Netral (skor 3); d. Setuju (skor 4); Sangat setuju (skor 5)

\subsubsection{Untuk mengukur variabel Kinerja Perusahaan}

Pengukuran variabel kinerja perusahaan, baik yang financial maupun non financial dilakukan juga dengan skala Likert yang diadopsi dari penelitian Jermias and Gani (2005). Adapun skor skala yang digunakan adalah: a. Sangat rendah (skor1); b. Rendah (skor 2); c. Sedang (skor 3); d. Tinggi (skor 4); e. Tinggi sekali (skor 5)

\subsection{Jenis dan Sumber Data}

Jenis data yang digunakan dalam penelitian ini adalah: Data Kualitatif, seperti sikap manajer keuangan dalam pengambilan keputusan yang berkaitan dengan mental accounting dan persepsi manajer keuangan terhadap penempatan dana untuk modal kerja dan kinerja perusahaan. Sumber Data yang digunakan adala Data primer, yaitu data yang diperoleh langsung dari obyek penelitian, yang berupa jawaban dari pernyataan yang ada di angket.

\subsection{Teknik Pengumpulan Data}

Teknik pengumpulan data yang digunakan dalam penelitian survei ini adalah dengan menggunakan angket, yaitu daftar yang mencakup semua pernyataan yang akan digunakan untuk mendapatkan data yang dilakukan melalui bertatap muka. 


\subsection{Alat Analisis}

Untuk mencapai tujuan penelitian serta pengujian hipotesis, maka data yang diperoleh akan diolah sesuai dengan kebutuhan analisis. Di dalam penelitian ini, data yang telah diperoleh akan diuji dengan menggunakan Generalized Structured Component Analysis (GSCA). GSCA dikembangkan oleh Heungsun Hwang, Hec Montreal dan Yhoshio Tahane pada tahun 2004. Tujuannya adalah menggantikan faktor dengan kombinasi linier dari indikator (variabel manifest) dalam analisis SEM. Pendekatan analisis ini menggunakan metode kuadrat terkecil (least square) di dalam proses pendugaan parameter. GSCA dikembangkan untuk menghindari kekurangan dari PLS (partial least square), yaitu dilengkapi dengan prosedur optimalisasi global dan juga dapat diterapkan pada hubungan antar variabel yang kompleks (bisa rekursif dan tidak rekursif), melibatkan higher-order komponen (faktor) dan perbandingan multi-group (Solimun, 2012).

\subsection{Karakteristik Responden}

\section{HASIL PENELITIAN DAN PEMBAHASAN}

Data responden menunjukkan 37,9 persen responden berusia antara 37 dan 45 tahun, 24 persen responden berusia lebih dari 54 tahun, 17,2 persen berusia antara 45 dan 54 tahun, 13,8 persen menunjukkan usia 30 sampai 37 tahun dan sisanya 6,9 persen berada pada kisaran umur 22 - 29 persen. Ditinjau dari usianya, sebagian besar manajer UKM di Pulau Lombok berada pada usia produktif. Artinya, para manajer UKM tersebut mempunyai kemampuan fisik untuk bekerja dan memiliki potensi berpikir dan bertindak secara efekif sehingga diharapkan dapat meningkatkan kinerja perusahaan.

Karakteristik responden berdasarkan jenis kelamin menunjukkan sebagian besar responden yaitu 72,4 persen berjenis kelamin laki-laki, sedangkan sisanya yaitu 27,6 persen berjenis kelamin perempuan. Artinya pengambil keputusan pada UKM industri gerabah di Pulau Lombok sebagian besar berjenis kelamin laki-laki, sehingga bisa dikatakan keberlangsungan usaha banyak didominasi kaum laki-laki selaku manajer sekaligus pemilik perusahaan. Hal ini terjadi karena pengelola UKM adalah kepala rumah tangga.

Karakteristik responden dilihat dari tingkat pendidikan menunjukkan sebagian besar tamatan SMA, yaitu sebesar 44,8 persen, sedangkan, tamatan Perguruan Tinggi dan SD mempunyai persentase yang sama yaitu 28,6 persen. Hal ini menunjukkan pendidikan para manajer berada pada tingkatan menengah yang akan berpengaruh dalam pengambilan keputusan.

Karakteristik responden berdasarkan jumlah karyawan yang dimiliki menunjukkan sebagian besar responden, yaitu 78,6 persen, memiliki karyawan tetap sampai dengan 10 orang. Jumlah ini memang sesuai dengan kriteria jumlah karyawan pada Usaha Kecil. Apabila ada pesanan dalam jumlah yang besar biasanya pemilik UKM menambah jumlah karyawannya. Dengan kata lain, perusahaan akan melakukan penambahan jumlah karyawan sewaktu-waktu apabila dibutuhkan.

Karakteristik responden dilihat dari lamanya usaha menunjukkan 39,2 persen sudah berusaha antara 10 dan 15 tahun, 28,6 persen antara 15- 20 tahun, 14,3 persen dari responden sudah menjalankan usaha antara 5 dan 10 tahun atau lebih dari 20 tahun dan yang menjalankan usaha kurang dari 5 tahun sebanyak 3,6 persen. Kondisi ini mencerminkan sebagian besar responden atau 82,1 persen sudah melangsungkan usahanya lebih dari 10 tahun. Hal ini menunjukkan manajer sekaligus pemilik UKM sudah banyak pengalaman dalam pengelolaan usaha yang dimiliki.

\subsection{Hasil Analisis Generalized Structured Component Analysis}

Metode analisis data yang digunakan dalam penelitian ini adalah Generalized Structured Component Analysis (GSCA). GSCA adalah model persamaan struktural (SEM) yang berbasis komponen atau varian (variance), Dalam penelitian ini, pengujian model struktural dan hipotesis penelitian dengan melihat nilai koefisien jalur dari variabel eksogen ke endogen dan melihat nilai signifikansi. Pengujian model struktural dalam GSCA dilakukan melalui resampling bootstrap. Evaluasi 
model struktural dan hipotesis bertujuan untuk mengetahui seberapa besar informasi yang dapat dijelaskan oleh model struktural (hubungan antara variabel laten). Lebih jelasnya uraian analisis dan evaluasi model pada GSCA penelitian ini sebagai berikut:

\subsubsection{Measure of Fit Structural Model}

Measure of Fit Structural Model diukur menggunakan FIT, yaitu setara dengan $\mathrm{R}^{2}$ pada analisis regresi atau koefisien determinasi total pada analisis jalur atau $\mathrm{Q}^{2}$ pada PLS, FIT menunjukkan varian total dari semua variabel yang dapat dijelaskan oleh model struktural. Nilai FIT berkisar dari 0 sampai 1, semakin besar nilai ini, semakin besar proporsi varian variabel yang dapat dijelaskan oleh model. Jika nilai FIT=1 berarti model secara sempurna dapat menjelaskan fenomena yang diselidiki. AFIT (Adjusted FIT) serupa dengan $\mathrm{R}^{2}$ adjusted pada analisis regresi. AFIT dapat digunakan untuk perbandingan model. Model dengan AFIT nilai terbesar dapat dipilih antara model yang lebih baik (Solimun, 2012).

Tabel 4. Hasil Penguiian Measure of fit Structural Model

\begin{tabular}{|c|c|}
\hline \multicolumn{2}{|c|}{ Model Fit } \\
\hline FIT & 0,569 \\
\hline AFIT & 0,540 \\
\hline
\end{tabular}

Hasil pengujian Measure of Fit Structural Model berdasarkan Tabel 4 memperlihatkan bahwa proporsi varian variabel yang dapat dijelaskan oleh model adalah sebesar 56,9\% atau keragaman mental accounting, keputusan penempatan dana untuk modal kerja dan kinerja perusahaan dijelaskan oleh model adalah sebesar 56,9\%. Sedangkan 43,1\% dijelaskan oleh faktor-faktor lain, seperti: volume penjualan, faktor musim dan siklus, perubahan dalam teknologi dan kebijakan perusahaan. Berarti model ini cukup baik untuk menjelaskan fenomena yang dikaji.

\subsubsection{Measurement Model Masing-masing Variabel}

Measurement Model diukur berdasarkan nilai loading factor (standardize coefficient) pada setiap indikator ke variabel laten. Nilai loading factor menunjukkan bobot setiap faktor sebagai pengukur masing-masing variabel. Indikator dengan loading factor terbesar menunjukkan bahwa indikator tersebut sebagai pengukur variabel dominan (terkuat).

Tabel 5. Hasil Pengujian Model Pengukuran Variabel Mental Accounting (X2)

\begin{tabular}{|c|c|c|c|c|c|c|c|c|c|}
\hline Variable & \multicolumn{3}{|c|}{ Loading } & \multicolumn{3}{|c|}{ Weight } & \multicolumn{3}{|c|}{ SMC } \\
\hline & Estimate & SE & CR & Estimate & SE & CR & Estimate & SE & CR \\
\hline $\mathrm{X} 1$ & & & & $\mathrm{VE}=0.86$ & Alph & $=0.904$ & & & \\
\hline X11 & 0.931 & 0.029 & $32.17^{\star}$ & 0.364 & 0.067 & $5.46^{*}$ & 0.867 & 0.053 & $16.34^{*}$ \\
\hline X12 & 0.928 & 0.025 & $36.7^{*}$ & 0.351 & 0.067 & $5.23^{*}$ & 0.861 & 0.046 & $18.63^{*}$ \\
\hline X13 & 0.923 & 0.031 & $29.64^{*}$ & 0.364 & 0.060 & $6.02^{*}$ & 0.852 & 0.055 & $15.43^{*}$ \\
\hline
\end{tabular}

Keterangan: $\mathrm{CR}^{*}=$ Signifikan pada $\alpha=0,05$

Variabel mental accounting, memiliki 3 indikator, dengan 7 pernyataan. Indikator pertama adalah kas dengan 2 pernyataan. Indikator kedua dari variabel ini adalah piutang dengan 2 pernyataan dan indikator ketiga yaitu persediaan dengan 3 pernyataan.

Tabel 5, menunjukkan nilai loading estimate yang diperoleh untuk setiap pernyataan. Pembuatan laporan kas masuk dan kas keluar mempunyai kontribusi yang besar dalam merefleksikan indikator kas. Indikator Piutang direfleksikan oleh pembuatan laporan piutang. Sedangkan Indikator Persediaan direfleksikan oleh penentuan harga produk sesuai dengan harga yang berlaku. Indikator kas adalah indikator variabel yang mempunyai peran atau kontribusi dominan dalam merefleksikan 
variabel mental accounting. Nilai rata-rata loading estimate indikator kas paling besar diantara kedua indikator yang lainnya yakni 0,931. Diikuti oleh indikator Piutang sebesar 0,928 dan terkecil indikator persediaan sebesar 0,923. Dengan melihat nilai titik kritis $(C R)$ yang diperoleh, indikator kas dapat digunakan untuk mengukur variabel mental accounting karena diperoleh nilai 32,17 signifikan pada $\alpha=$ 0,05 jika dibandingkan dengan indikator piutang dan persediaan.

Hasil analisis terhadap measurement model variabel mental accounting diperoleh ketiga indikator, yaitu kas, piutang dan persediaan valid untuk digunakan dalam mendeskripsikan pengukuran variabel mental accounting. Hasil ini dapat dilihat dari nilai loading estimate ketiga indikator secara keseluruhan memiliki nilai lebih besar dari 70 persen dan nilai $C R$ signifikan pada tingkat kepercayaan 95 persen. Mencerminkan bahwa korelasi antara semua indikator variabel positif dan signifikan dalam merefleksikan variabel mental accounting.

Nilai AVE variabel mental accounting sebesar 0,860. Apabila dibandingkan nilai square root of AVE yang dimiliki indikator variabel mental accounting dengan nilai korelasi antar variabel laten lainnya dalam model bisa dikatakan variabel ini memiliki discriminant validity yang baik, karena nilai square root of $A V E$ nya lebih besar dibandingkan dengan nilai korelasi seluruh variabel laten lainnya. Dengan demikian, instrumen penelitian yang digunakan untuk mengukur variabel mental accounting memenuhi kriteria validitas diskriminan. Hasil analisis data menunjukkan nilai alpha yang diperoleh sebesar 0,904, yang artinya variabel mental accounting memiliki konsistensi reliabilitas internal yang baik karena lebih besar dari 0,6. Dapat disimpulkan bahwa instrumen penelitian yang digunakan untuk pengukuran variabel mental accounting layak untuk diterima dari ketiga indikator variabel karena memiliki kesesuaian dan keandalan yang tinggi.

Hasil pengujian menunjukkan kas adalah sumber dana utama dan diharapkan yang dimiliki oleh UKM dalam melaksanakan operasionalnya. Pengelolaan kas yang dilakukan adalah membuat laporan kas masuk dan kas keluar.

Tabel 6. Hasil Pengujian Model Pengukuran

Variabel Penempatan Dana untuk Modal Kerja (Y1)

\begin{tabular}{|c|c|c|c|c|c|c|c|c|c|c|}
\hline Variable & \multicolumn{4}{|c|}{ Loading } & \multicolumn{3}{c|}{ Weight } & \multicolumn{3}{c|}{ SMC } \\
\hline & Estimate & SE & CR & Estimate & SE & CR & Estimate & SE & CR \\
\hline Y1 & \multicolumn{9}{|c|}{ AVE = 0.861, Alpha =0.922 } \\
\hline Y11 & 0.871 & 0.068 & $12.9^{*}$ & 0.267 & 0.079 & $3.4^{*}$ & 0.759 & 0.114 & $6.67^{*}$ \\
\hline Y12 & 0.955 & 0.019 & $50.32^{*}$ & 0.493 & 0.088 & $5.63^{*}$ & 0.912 & 0.036 & $25.18^{*}$ \\
\hline Y13 & 0.955 & 0.018 & $52.13^{*}$ & 0.310 & 0.097 & $3.2^{*}$ & 0.911 & 0.035 & $26.34^{*}$ \\
\hline
\end{tabular}

Keterangan: $\mathrm{CR}^{*}=$ Signifikan pada $\alpha=0,05$

Variabel keputusan investasi/penempatan dana untuk modal kerja (Y1) mempunyai 3 indikator dengan 9 pernyataan. Indikator pertama, yaitu Efficiency of Cash Management (ECM), dengan 3 pernyataan. Indikator kedua yaitu Efficiency of Receivables Management (ERM) dengan 3 pernyataan dan indikator ketiga, Efficiency of inventory management (EIM) memiliki 3 pernyataan.

Pengujian model pengukuran variabel keputusan investasi (penempatan dana untuk modal kerja) pada Tabel 6 diperoleh bahwa nilai estimate loading ketiga variabel secara keseluruhan memiliki nilai $C R$ signifikan pada $a=0,05$. Artinya ketiga indikator yang digunakan valid untuk merefleksikan pengukuran variabel penempatan dana untuk modal kerja. Hasil analisis mencerminkan pula bahwa korelasi antara semua indikator variabel positif dan signifikan dalam merefleksikan variabel keputusan investasi (penempatan dana untuk modal kerja). Hasil pengujian nilai loading estimate yang diperoleh setiap indikator, indikator EIM memiliki peran dominan dalam merefleksikan variabel keputusan investasi (penempatan dana untuk modal kerja). Nilai rata-rata loading estimate indikator EIM paling besar di antara kedua indikator yang lainnya yakni sebesar 0,955 (dengan pertimbangan SE dan CR dibandingkan dengan ERM). Selanjutnya secara berturut-turut dikuti oleh indikator ERM dan ECM. 
Selain itu dapat dibuktikan dengan nilai titik kritis $(C R)$ yang diperoleh, indikator EIM paling baik bila digunakan untuk mengukur variabel Penempatan Dana untuk Modal Kerja karena diperoleh nilai CR yang paling besar yaitu 52,13 signifikan pada $\alpha=0,05$. Hasil pengujian juga menunjukkan adanya efisiensi dalam manajemen persediaan yang direfleksikan oleh penyediaan anggaran untuk persediaan.

Nilai AVE variabel keputusan investasi (penempatan dana untuk modal kerja) sebesar 0,861. Apabila dibandingkan nilai square root of $A V E$ yang dimiliki indikator variabel keputusan investasi (penempatan dana untuk modal kerja) dengan nilai korelasi antar variabel laten lainnya dalam model bisa dikatakan variabel ini memiliki discriminant validity yang baik, karena nilai square root of AVE nya lebih besar dibandingkan dengan nilai korelasi seluruh variabel laten lainnya. Dengan demikian, instrumen penelitian yang digunakan untuk mengukur variabel penempatan dana untuk modal kerja memenuhi kriteria validitas diskriminan. Hasil analisis data menunjukkan nilai alpha yang diperoleh sebesar 0,922, yang artinya variabel penempatan dana untuk modal kerja memiliki konsistensi reliabilitas internal yang baik karena lebih besar dari 0,6. Dapat disimpulkan bahwa instrumen penelitian yang digunakan untuk pengukuran variabel penempatan dana untuk modal kerja layak untuk diterima dari ketiga indikator variabel karena memiliki kesesuaian dan keandalan yang tinggi.

Tabel 7. Hasil Pengujian Model Pengukuran Variabel Kinerja Perusahaan (Y2)

\begin{tabular}{|c|c|c|c|c|c|c|c|c|c|}
\hline Variable & \multicolumn{3}{|c|}{ Loading } & \multicolumn{3}{|c|}{ Weight } & \multicolumn{3}{|c|}{ SMC } \\
\hline & Estimate & SE & CR & Estimate & SE & CR & Estimate & SE & CR \\
\hline $\mathrm{Y} 2$ & & & & $\mathrm{AVE}=0.0$ & Alpha & 0.947 & & & \\
\hline$Y 21$ & 0 & 0 & 0 & 0.898 & 0.296 & $3.03^{*}$ & 0 & 0 & 0 \\
\hline Y22 & 0 & 0 & 0 & 0.111 & 0.315 & 0.35 & 0 & 0 & 0 \\
\hline
\end{tabular}

Keterangan: $\mathrm{CR}^{*}=$ Signifikan pada $\mathrm{\alpha}=0,05$

Variabel kinerja perusahaan merupakan satu-satunya variabel yang bersifat formatif. Variabel ini mempunyai dua indikator dengan masing-masing tiga pernyataan. Variabel kinerja perusahaan paling dibentuk oleh indikator kinerja financial. Berdasarkan nilai titik kritis $(C R)$ yang diperoleh, indikator kinerja financial yang berkaitan dengan pertumbuhan penjualan dapat digunakan untuk mengukur variabel kinerja perusahaan karena diperoleh nilai titik kritis 3,03 dan signifkan pada $\alpha=$ 0,05 .

\subsubsection{Model Struktural}

Dalam model struktural ini, diuji 3 (tiga) hipotesis hubungan. Hasil pengujian hubungan antar variabel penelitian secara lengkap disajikan pada Tabel 8.

Tabel 8. Model GSCA: Pengaruh Langsung

\begin{tabular}{|l|c|c|}
\hline \multicolumn{1}{|c|}{ Hubungan Antar Variabel } & Koefisien & Keterangan \\
\hline $\begin{array}{l}\text { Mental Accounting terhadap Penempatan } \\
\text { dana untuk modal kerja }\end{array}$ & 0,531 & Signifikan \\
\hline $\begin{array}{l}\text { Penempatan dana untuk modal kerja } \\
\text { terhadap Kinerja Perusahaan }\end{array}$ & 0,831 & Signifikan \\
\hline
\end{tabular}

Gambar 1. Model Struktural Penelitian

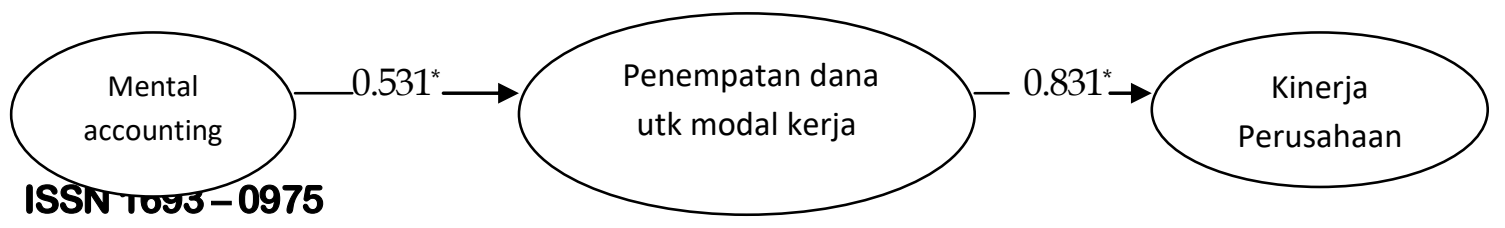


*: signifikan pada $\alpha=0,05$

Pengujian hipotesis sebagai berikut:

a. Nilai koefisien pengaruh mental accounting terhadap penempatan dana untuk modal kerja sebesar 0,531 , dan signifkan pada $a=0,05$, dapat disimpulkan pengaruh mental accounting terhadap keputusan investasi signifikan, artinya semakin kuat mental accounting yang dimiliki oleh manajer UKM semakin besar modal kerja yang diinvestasikan pada usahanya.

b. Nilai koefisien pengaruh penempatan dana untuk modal kerja terhadap kinerja perusahaan sebesar 0,831 dan signifkan pada $\alpha=0,05$, maka dapat disimpulkan pengaruh penempatan dana untuk modal kerja terhadap kinerja perusahaan signifikan, artinya semakin besar modal kerja yang diinvestasikan pemilik UKM, semakin tinggi kinerja perusahaan yang diperoleh.

Perhitungan nilai koefisien pengaruh tidak langsung (indirect effect) diperoleh dari hasil perkalian 2 (dua) nilai koefisien pengaruh langsung. Pengaruh tidak langsung dinyatakan signifikan jika sudah dilakukan uji Sobel yaitu $z$ _value, dihitung dengan pembagian koefisien pengaruh langsung dengan standart errornya. Hasil pengujian pengaruh tidak langsung disajikan pada Tabel 9.

Tabel 9. Hasil Pengujian Pengaruh Tidak Langsung

\begin{tabular}{|c|c|c|c|c|c|c|c|}
\hline $\begin{array}{l}\text { Pengaruh Tidak } \\
\text { Langsung }\end{array}$ & \multicolumn{4}{|c|}{ Nilai Koefisien Pengaruh Langsung } & $\begin{array}{c}\text { Nilai } \\
\text { Koefisien } \\
\text { Pengaruh } \\
\text { Tidak } \\
\text { Langsung }\end{array}$ & $\begin{array}{l}\text { P-Va } \\
\text { lue }\end{array}$ & Ket. \\
\hline $\begin{array}{c}\text { Mental } \\
\text { Accounting } \\
>\text { Keputusan } \\
\text { Investasi > } \\
\text { Kinerja } \\
\text { Perusahaan }\end{array}$ & $\begin{array}{c}\text { Mental } \\
\text { Accounting > } \\
\text { Keputusan } \\
\text { Investasi }\end{array}$ & 0,531 & $\begin{array}{c}\text { Keputusan } \\
\text { Investasi > } \\
\text { Kinerja } \\
\text { Perusahaan }\end{array}$ & 0,831 & 0,441 & 0,000 & $\begin{array}{l}\text { Mediasi } \\
\text { Signifikan }\end{array}$ \\
\hline
\end{tabular}

Keterangan : $>=$ terhadap

Berdasarkan Tabel 9 dapat diuraikan hasil pengujian pengaruh tidak langsung model struktural sebagai berikut :

Berdasarkan hasil analisis pengaruh tidak langsung mental accounting terhadap kinerja perusahaan melalui keputusan investasi (penempatan dana untuk modal kerja) diperoleh koefisien pengaruh tidak langsung sebesar 0,441 . Karena p-value $(0,000)<a(0.05)$, dapat disimpulkan terdapat pengaruh tidak langsung yang signifikan mental accounting terhadap kinerja perusahaan melalui keputusan investasi. Artinya, semakin kuat mental accounting yang dimiliki oleh manajer UKM semakin tinggi kinerja perusahaan yang diperoleh, jika semakin besar modal kerja yang diinvestasikan pada usahanya.

\subsection{Hubungan Antara Nilai Rerata (Mean) dan Model Pengukuran}

Hasil evaluasi responden terhadap indikator pengukuran variabel penelitian ini dicerminkan melalui nilai rerata. Evaluasi ini dimaksudkan untuk mengetahui kondisi aktual setiap indikator yang dipersepsikan responden (manajer sekaligus pemilik UKM). Nilai rerata terbesar dapat diartikan sebagai indikator yang diprioritaskan dalam pelaksanaannya menurut penilaian responden. Nilai loading estimate atau weight estimate tertinggi menunjukkan indikator pengukur variabel yang terkuat 
atau dapat diinterpretasikan sebagai indikator yang memiliki kontribusi dominan dalam merefleksikan/meformatifkan variabel.

Tabel 10. Rekapitulasi Nilai Loading Factor dan Rerata Indikator Variabel Mental Accounting

\begin{tabular}{|c|l|c|c|}
\hline No. & \multicolumn{1}{|c|}{ Indikator } & Loading Estimate & Rerata Indikator \\
\hline 1 & Kas & 0,931 & 3,74 \\
\hline 2 & Piutang & 0,928 & 3,96 \\
\hline 3 & Persediaan & 0,923 & 4,06 \\
\hline
\end{tabular}

Tabel 10 menunjukkan Variabel mental accounting dengan 3 (tiga) indikator. Indikator pertama, yaitu kas mempunyai nilai rerata sebesar 3,74 menunjukkan mental accounting yang berkaitan dengan kas belum dilaksanakan dengan baik walaupun mental accounting direfleksikan oleh kas. Hal ini dibuktikan dengan manajer UKM belum menghitung kebutuhan kas untuk periode yang akan datang dan membuat laporan kas masuk dan kas keluar. Indikator kedua, yaitu piutang, mempunyai nilai rerata sebesar 3,96. Artinya mental accounting yang berkaitan dengan piutang juga belum dilaksanakan dengan baik. Hal ini terlihat dari manajer UKM yang belum membuat daftar penagihan piutang dan laporan piutang. Indikator ketiga yaitu persediaan, memiliki nilai rerata sebesar 4,06. Artinya, mental accounting yang berkaitan dengan persediaan sudah dilaksanakan dengan baik. Hal ini dapat dilihat dari manajer UKM sudah menentukan harga sesuai dengan harga berlaku, membuat laporan persediaan dan memperhitungkan bahwa lamanya produk mengendap akan mendatangkan kerugian. Hal ini berarti harga produk pada saat dijual sudah disesuaikan dengan harga yang berlaku pada saat itu, sehingga usaha yang dijalankan terhindar dari potensi kerugian. Tersedianya laporan persediaan memudahkan manajer UKM untuk mengidentifikasi persediaan karena mempunyai catatan mengenai persediaan yang sudah laku dan yang masih ada. Penghindaran pengendapan produk dalam waktu yang lama akan mengurangi risiko kerugian, misalnya produk menjadi menurun kualitasnya atau produk tersebut menjadi cacat (rusak).

Dari ketiga indikator tersebut, indikator yang paling merefleksikan variabel mental accounting adalah kas, dengan nilai loading estimate yang paling besar diantara dua indikator yang lain, yaitu sebesar 0,931 dengan nilai rerata sebesar 3,74. Artinya mental accounting direfleksikan oleh kas tapi belum dilaksanakan dengan baik.

Tabel 11. Rekapitulasi Nilai Loading Factor dan Rerata Indikator Variabel Penempatan dana untuk modal kerja

\begin{tabular}{|c|l|c|c|}
\hline No. & \multicolumn{1}{|c|}{ Indikator } & Loading Estimate & $\begin{array}{c}\text { Rerata } \\
\text { Indikator }\end{array}$ \\
\hline 1 & Efficiency of Cash Management (ECM) & 0,871 & 4,19 \\
\hline 2 & Efficiency of Receivables Management (ERM) & 0,955 & 4,35 \\
\hline 3 & Efficiency of Inventory Management (EIM) & 0,955 & 4,24 \\
\hline
\end{tabular}

Tabel 11 menunjukkan variabel penempatan dana untuk modal kerja dengan 3 (tiga) indikator. Indikator pertama, yaitu ECM, memiliki nilai rerata sebesar 4,19, artinya manajer UKM sudah melakukan persiapan anggaran kas, menentukan saldo yang ingin dicapai dan selalu melakukan perhitungan berapa jumlah kas yang seharusnya tersedia. Indikator kedua, yaitu ERM, memilki nilai rerata sebesar 4,35, artinya manajer sekaligus pemilik UKM selalu menyiapkan pedoman kredit untuk pelanggan, pemeriksaan tingkat piutang dan memeriksa tingkat kredit macet. Indikator ketiga yaitu 
EIM, mempunyai nilai rerata sebesar 4,24, artinya manajer sekaligus pemilik UKM sudah melakukan persiapan anggaran persediaan, memeriksa tingkat persediaan dan mengantisipasi jumlah persediaan. Dari ketiga indikator ini yang paling merefleksikan variabel penempatan dana untuk modal kerja adalah indikator EIM, ditunjukkan oleh nilai loading estimate yang paling besar yaitu 0,955 (dengan mempertimbangkan SE dan CR). Berdasarkan nilai rerata yang diperoleh masing-masing indikator, menunjukkan telah terjadi efisiensi dalam pengambilan keputusan investasi yaitu penempatan dana untuk modal kerja.

Tabel 12. Rekapitulasi Nilai Loading Factor dan Rerata Indikator Variabel Kinerja Perusahaan

\begin{tabular}{|c|l|c|c|}
\hline No. & \multicolumn{1}{|c|}{ Indikator } & Weight Estimate & $\begin{array}{c}\text { Rerata } \\
\text { Indikator }\end{array}$ \\
\hline 1 & Kinerja Financial & 0,898 & 3,01 \\
\hline 2 & Kinerja Non Financial & 0,111 & 3,35 \\
\hline
\end{tabular}

Tabel 12 menunjukkan variabel kinerja perusahaan, terdiri atas dua indikator, yaitu kinerja financial dan kinerja non financial. Kinerja financial mempunyai nilai rerata sebesar 3,01 menunjukkan kinerja financial yang dihasilkan masih sedang. Penyebabnya adalah persaingan antar UKM gerabah dalam merebut pangsa pasar yang ada. Untuk dapat meningkatkan kinerja financial perlu dtingkatkan lagi pertumbuhan penjualan. Salah satu cara yang dapat dilakukan adalah promosi melalui internet. Kinerja non financial mempunyai nilai rerata sebesar 3,35, artinya kinerja non financial yang dihasilkan juga masih sedang. Hal ini disebabkan karena kualitas sumberdaya manusia yang ada belum memadai. Pelatihan-pelatihan yang sudah diperoleh belum bisa diterapkan dalam kegiatan perusahaan.

Kinerja perusahaan paling dibentuk oleh kinerja financial dengan nilai estimate weight sebesar 0,898. Artinya, untuk dapat meningkatkan kinerja UKM yang menjadi prioritas untuk ditingkatkan adalah kinerja financial terutama peningkatan penjualan. Salah satu cara yang dapat dilakukan adalah promosi melalui internet, misalnya dengan membuat website atau blog. Apabila hal ini dapat dilaksanakan dengan baik maka akan tercapai kinerja UKM seperti yang diharapkan.

\subsection{Hasil Pengujian Hipotesis Penelitian}

Penelitian ini mengajukan sebanyak 3 hipotesis. Hasil penelitian menunjukkan bahwa terdapat semua hipotesis diterima.Hasil pengujian hipotesis tersebut dapat diuraikan sebagai berikut:

\subsubsection{Mental Accounting Berpengaruh Signifikan terhadap Penempatan Dana untuk Modal Kerja pada UKM}

Berdasarkan hasil analisis, nilai koefisien hubungan antara mental accounting dengan penempatan dana untuk modal kerja adalah sebesar 0,531 dan signifikan pada $a=0,05$. Hal ini mengindikasikan bahwa pengaruh mental accounting terhadap penempatan dana untuk modal kerja signifikan, artinya semakin kuat mental accounting yang dimiliki oleh manajer UKM semakin besar modal kerja yang diinvestasikan pada usahanya.

\subsubsection{Keputusan Penempatan Dana untuk Modal Kerja Berpengaruh Signifikan terhadap Kinerja} Perusahaan pada UKM 
Berdasarkan hasil analisis, nilai koefisien hubungan antara penempatan dana untuk modal kerja dengan kinerja perusahaan adalah sebesar 0,831 dan signifikan pada $\alpha=0,05$ mengindikasikan bahwa pengaruh penempatan dana untuk modal kerja terhadap kinerja perusahaan signifikan. Artinya semakin besar modal kerja yang diinvestasikan oleh manajer UKM, semakin tinggi kinerja perusahaan yang diperoleh.

\subsubsection{Mental Accounting Berpengaruh Signifikan terhadap Kinerja Perusahaan melalui Keputusan Penempatan Dana untuk Modal Kerja pada UKM}

Hubungan lain juga ditelusuri melalui pengujian pengaruh tidak langsung mental accounting terhadap kinerja perusahaan melalui keputusan investasi. Berdasarkan hasil analisis pengaruh tidak langsung mental accounting terhadap kinerja perusahaan melalui penempatan dana untuk modal kerja diperoleh koefisien pengaruh tidak langsung sebesar 0,441 dan signifikan pada $\alpha=0,05$, dapat disimpulkan terdapat pengaruh tidak langsung yang signifikan mental accounting terhadap kinerja perusahaan melalui keputusan investasi. Artinya, semakin kuat mental accounting yang dimiliki oleh manajer UKM semakin tinggi kinerja perusahaan yang diperoleh, jika semakin besar modal kerja yang diinvestasikan pada usahanya..

\subsection{Pembahasan Hasil Penelitian}

Teori yang digunakan dalam mental accounting adalah teori prospek. Konsep mental accounting sama dengan yang digunakan dalam teori prospek yang menilai pilihan keputusan investasi dalam konteks potensi keuntungan dan kerugian (portfolio) dan banyak mengadopsi teori ini sebagai fungsi nilai dalam analisisnya. Ide utama adalah pembuat keputusan cenderung memisahkan tipe berbeda dari spekulasi ke dalam account terpisah, dan kemudian mempergunakan teori prospek pada tiap-tiap account.

Dalam konsep mental accounting diasumsikan bahwa manusia membagi uangnya ke dalam kelompok-kelompok tertentu berdasarkan tujuan pemanfaatan uang tersebut. Investor mungkin saja berperilaku berbeda untuk setiap kelompok atau account. Thaler menunjukkan konsistensinya dalam meneliti masalah mental accounting ini, seperti tampak pada beberapa penelitiannya ditahun 1980, 1985, 1990, dan 1999. Thaler (1999) mendefinisikan Mental Accounting is the set cognitive operation used by individuals and households to organize, evaluate, and keep track of financial activities. Asri (2013:301) menyatakan mental accounting adalah cara memandang manusia, mengelompokkan dan memperlakukan kekayaannya. Manusia memandang dan memperlakukan kekayaannya dengan melihat hubungan kekayaan tersebut dengan: a) Kemampuan mendapatkan penghasilan saat ini (current income), b) Kekayaan yang dimiliki saat ini (current wealth), dan c) Kemampuan memperoleh penghasilan di masa yang akan datang (future income). Widyastuti (2011:9) mengatakan bahwa mental accounting dapat dilihat pada kecenderungan investor untuk mengelompokkan keuangan mereka pada rekening yang berbeda-beda didasarkan pada kriteria-kriteria yang subjektif, seperti sumber pendanaan dan maksud pemanfaatan penghasilan. Mental accounting sering didefinisikan sebagai proses pengodean, pengategorisasian dan pengevaluasian hasil suatu keputusan (outcomes) terutama yang bersifat financial (Henderson dan Peterson, 1992; Tversky dan Kahneman, 1984 dalam Prakoso, 2009). Dari uraian tersebut dapat dikatakan bahwa mental accounting dapat ditunjukkan oleh sikap bagaimana implementasi akuntansi oleh individu dalam akivitas keuangan.

Pada penelitian ini mental accounting direfleksikan oleh 3 (tiga) indikator, yaitu kas, piutang dan persediaan. Mental accounting yang berkaitan dengan kas belum dilaksanakan dengan baik, dibuktikan dengan manajer sekaligus pemilik UKM belum menghitung kebutuhan kas untuk periode yang akan datang dan belum membuat laporan kas masuk dan kas keluar. Mental accounting yang berkaitan piutang belum juga dilaksanakan dengan baik. Hal ini terlihat dari manajer UKM belum membuat daftar penagihan piutang dan laporan piutang. Mental accounting yang berkaitan dengan persediaan sudah dilaksanakan dengan baik. Hal ini dapat dilihat dari manajer sekaligus pemilik 
UKM sudah menentukan harga sesuai dengan harga berlaku, membuat laporan persediaan dan memperhitungkan bahwa lamanya produk mengendap akan menghindari kerugian. Hal ini berarti harga produk pada saat dijual sesuai dengan harga yang berlaku pada saat itu, sehingga usaha yang dijalankan dapat menguntungkan. Tersedianya laporan persediaan memudahkan manajerr UKM untuk mengidentifikasi persediaan yang sudah laku dan yang masih ada. Penghindaran produk mengendap dalam waktu yang lama akan mencegah risiko kerugian, misalnya produk menjadi menurun kualitasnya atau produk tersebut menjadi cacat (rusak) sehingga menurunkan harga jualnya.

Mental accounting paling direfleksikan oleh kas. Hal ini berarti, kas adalah dana utama dan diharapkan oleh UKM. Salah satu cara pengelolaan kas dapat dilakukan dengan menghitung kebutuhan kas pada periode yang akan datang berdasarkan target yang telah ditetapkan sebelumnya dan membuat laporan kas masuk dan kas keluar. Secara psikologis, dilihat dari aspek affective menunjukkan mental accounting yang kuat dimiliki oleh manajer UKM dapat meningkatkan dana yang diinvestasikan untuk modal kerja sehingga kinerja perusahaan meningkat juga. Aspek psycohomotorik dalam variabel mental accounting terlihat bahwa belum dilaksanakan dengan baik kegiatan-kegiatan yang berkaitan dengan kebutuhan kas dan pembuatan laporan. Selama ini yang terjadi pada saat penggunaan modal kerja untuk produksi adalah menghitung keuntungan yang akan diperoleh dari produksi yang dilakukan pada saat itu saja tanpa memperhitungkan kebutuhan kas untuk periode yang akan datang dan belum melakukan secara kontinyu pembuatan laporan kas masuk dan kas keluar, artinya pembuatan laporan kas masuk dan kas keluar sudah dilakukan tapi tidak secara terus menerus hanya pada saat diperlukan saja. Dengan demikian, dapat dikatakan mental accounting yang dimiliki oleh manajer sekaligus pemilik UKM bersifat rasional. Mereka menyadari bahwa kas yang ada merupakan sumber utama bagi usahanya. Hal ini ditunjukkan oleh perhitungan keuntungan yang akan diperoleh pada saat penanaman modal kerja dan melakukan pencatatan kas masuk dan kas keluar walaupun belum secara kontinyu.

Temuan studi ini konsisten dan memperluas hasil studi Rockenbach (2002) dan Baptista (2012). Perbedaan obyek penelitian antara kedua penelitian sebelum dengan penelitian ini ternyata menghasilkan temuan yang sama, yaitu sama-sama menyatakan ada pengaruh signifikan variabel mental accounting terhadap keputusan investasi. Lebih jelasnya penelitian ini menghasilkan temuan bahwa ada pengaruh signifikan variabel mental accounting dengan indikator kas, piutang dan persediaan terhadap keputusan investasi (penempatan dana untuk modal kerja).

Variabel Keputusan Investasi/Penempatan dana untuk modal kerja direfleksikan oleh 3 (tiga) indikator, yaitu Efficiency of Cash Management (ECM), Efficiency of Receivables Management (ERM), dan Efficiency of Inventory Management (EIM). ECM ditunjukkan oleh manajer UKM yang sudah melakukan persiapan anggaran kas, menentukan saldo yang ingin dicapai dan selalu melakukan perhitungan berapa jumlah kas yang seharusnya tersedia. ERM ditunjukkan manajer UKM dengan selalu menyiapkan pedoman kredit untuk pelanggan, pemeriksaan tingkat piutang dan memeriksa tingkat kredit macet. Selain itu juga manajer UKM sudah melakukan persiapan anggaran persediaan, memeriksa tingkat persediaan dan mengantisipasi jumlah persediaan, yang menunjukkan sudah terjadi EIM. Keputusan investasi (penempatan dana untuk modal kerja) paling direfleksikan oleh EIM, tetapi efisiensi tidak hanya dicapai oleh manajemen persediaan tetapi juga manajemen kas dan manajemen piutang. Secara psikologis, dilihat dari aspek psycohomotorik ditunjukkan dengan sudah dilakukan pembuatan anggaran kas, penentuan saldo yang ingin dicapai, perhitungan jumlah kas yang tersedia, pedoman kredit, dan kegiatan-kegiatan yang menunjang efisiensi dalam keputusan penempatan dana untuk modal kerja. Aspek cognitive ditunjukkan oleh pengambilan keputusan investasi penempatan dana untuk modal kerja yang direfleksikan oleh efisiensi dalam manajemen kas, piutang dan persediaan. 
Kinerja financial paling membentuk kinerja perusahaan tetapi belum menghasilkan kinerja perusahaan yang optimal. Hal ini menggambarkan bahwa kinerja keuangan yang ada di UKM harus didukung oleh peningkatan penjualan sehingga menghasilkan keuntungan sesuai dengan yang diharapkan. Cara yang dapat dilakukan adalah peningkatan strategi promosi dengan menggunakan fasilitas internet melalui pembuatan website atau blog UKM, sehingga dapat memperluas pemasaran produk, yang harus diikuti dengan pengembangan produk baik dari segi peningkatan kuantitas maupun kualitas produk. Kinerja non financial UKM juga belum bisa dikatakan optimal. Hal ini disebabkan karena manajer UKM belum menyadari pentingnya peningkatan kualitas sumber daya manusia walaupun sudah mendapatkan pelatihan yang berkaitan dengan pengembangan UKM, tapi masih belum bisa menerapkan pada usahanya. Salah satu contoh yang paling sering dilakukan pada pengelolaan keuangan adalah ketidakdisiplinan manajer UKM dalam memisahkan uang pribadi dengan uang yang harus dikelola oleh perusahaan. Selain itu juga, UKM masih belum menerapkan sistem akuntansi yang baik dalam pengelolaan keuangan secara keseluruhan.

Temuan ini memperluas hasil penelitian yang dilakukan oleh Hayajneh and Yassine (2011), Nyamao, et al. (2012), Eichholtz and Yonder (2011) dan Caballero, et al. (2011) walaupun dengan mengambil objek penelitian yang berbeda tetapi hasil temuannya sama yaitu ada pengaruh keputusan investasi terhadap kinerja perusahaan. Lebih jelasnya, hasil penelitian ini menyatakan keputusan investasi (penempatan dana untuk modal kerja) dengan indikator yaitu Efficiency of Cash Management (ECM), Efficiency of Receivables Management (ERM), dan Efficiency of inventory management (EIM ) berpengaruh signifikan terhadap kinerja perusahaan.

\subsection{Tinjauan dari Segi Perspektif Perilaku (Cognitive, Affective dan Psychomotorik)}

Kemampuan sumberdaya manusia juga dapat dilihat dari perspektif perilaku. Menurut Bloom (1908) dalam Notoatmodjo (2003), Perspektif perilaku manusia terdiri dari tiga aspek yaitu cognitive, affective dan psychomotorik.

Aspek cognitive berorientasi pada Kemampuan berfikir yang mencakup kemampuan intelektual yang lebih sederhana, yaitu mengingat, sampai pada kemampuan memecahkan masalah. Dengan demikian aspek cognitive adalah subtaksomi yang mengungkapkan tentang kegiatan mental yang sering berawal dari tingkat pengetahuan sampai ke tingkat yang paling tinggi yaitu evaluasi. Pada penelitian ini aspek cognitive terlihat pada pengambilan keputusan investasi, yaitu penempatan dana untuk modal kerja. Dari hasil wawancara dengan manajer UKM, diperoleh informasi bahwa dalam menempatkan dana untuk modal kerja mereka sudah memperhitungkan kebutuhan kas, piutang dan persediaan. Modal kerja yang ada sebagian besar diinvestasikan untuk produksi gerabah. Keputusan investasi pada modal kerja yang dilakukan oleh manajer UKM bisa dikatakan tepat dilihat dari telah terjadinya efisiensi pada manajemen kas, piutang dan persediaan.

Aspek affective berkaitan dengan sikap dan nilai. Affective mencakup watak perilaku seperti perasaan, minat, sikap, emosi dan nilai. Dalam penelitian ini affective bisa digambarkan dari, mental accounting. Berdasarkan hasil penelitian, manajer UKM mempunyai mental accounting yang kuat.

Aspek psycohomotorik berkaitan dengan keterampilan (skill) atau kemampuan bertindak setelah seseorang menerima pengalaman belajar tertentu. Dalam penelitian ini, aspek tersebut bisa dilihat dari penentuan harga produk sesuai dengan harga yang berlaku, pembuatan laporan persediaan, perhitungan produk yang mengendap untuk menghindari kerugian dan kegiatan-kegiatan yang menunjang efisiensi dalam keputusan penempatan dana untuk modal kerja.

Dengan demikian bisa dikatakan bahwa secara psikologis manajer sekaligus pemilik UKM rasional dalam pengambilan keputusan investasi (penempatan dana untuk modal kerja). Beberapa faktor penyebabnya, yaitu: sebagian besar manajer sekaligus pemilik UKM adalah laki-laki, usia masih produktif dan pengalaman dalam bidang industri gerabah lebih dari 10 (sepuluh) tahun. Hal ini berbeda dengan yang ada di pasar modal, dimana keputusan untuk melakukan investasi atau portfolio, 
harus diputuskan dalam waktu yang singkat dengan risiko yang tinggi, sehingga kadangkala keputusan yang diambil oleh investor tidak sepenuhnya rasional (quasy rational), yang akhirnya akan berpengaruh terhadap hasil yang diperoleh.

\subsection{Kesimpulan}

\section{KESIMPULAN DAN SARAN}

Berdasarkan pengujian hipotesis, hasil pembahasan dan temuan penelitian, dapat dikemukakan beberapa kesimpulan sebagai berikut:

1. Mental accounting yang kuat dimiliki oleh manajer sekaligus pemilik UKM dapat meningkatkan penempatan dana untuk modal kerja sehingga dapat meningkatkan kinerja perusahaan. Mental accounting paling direfleksikan oleh kas. Kas merupakan dana utama dan diharapkan oleh UKM.

2. Meningkatnya penempatan dana untuk modal kerja mengakibatkan semakin tinggi kinerja perusahaan yang dihasilkan oleh UKM. Keputusan Investasi (Penempatan dana untuk modal kerja) paling direfleksikan oleh Efficiency of inventory management (EIM). Kinerja financial paling membentuk kinerja perusahaan tetapi belum menghasilkan kinerja perusahaan yang optimal. Hal ini menggambarkan bahwa kinerja keuangan yang ada di UKM harus didukung oleh peningkatan penjualan sehingga menghasilkan keuntungan sesuai dengan yang diharapkan. Cara yang dapat dilakukan adalah peningkatan strategi promosi dengan menggunakan fasilitas internet melalui pembuatan website atau blog UKM, sehingga dapat memperluas pemasaran produk, yang harus diikuti dengan pengembangan produk baik dari segi peningkatan kuantitas maupun kualitas produk. Kinerja non financial UKM juga belum bisa dikatakan optimal. Hal ini disebabkan manajer UKM sekaligus pemilik belum menyadari pentingnya peningkatan kualitas sumber daya manusia walaupun sudah mendapatkan pelatihan yang berkaitan dengan pengembangan UKM, tapi masih belum bisa menerapkan pada usahanya.

Dengan demikian mental accounting berpengaruh signifikan terhadap kinerja perusahaan melalui keputusan investasi penempatan dana untuk modal kerja. Selain itu juga bisa dikatakan bahwa secara psikologis manajer sekaligus pemilik UKM rasional dalam pengambilan keputusan investasi (penempatan dana untuk modal kerja). Hal ini dilatarbelakangi oleh sebagian besar manajer sekaligus pemilik UKM laki-laki, berusia masih produktif dan berpengalaman dibidangnya lebih dari 10 tahun.

Dapat ditegaskan bahwa teori prospek yang ditunjukkan oleh perilaku investor dalam pengambilan keputusan investasi di pasar modal bersifat irasional. Berbeda dengan perilaku manajer sekaligus pemilik UKM di dalam pengambilan keputusan investasi yang bersifat rasional. Perbedaan ini disebabkan oleh risiko yang dihadapi dan waktu yang dipergunakan dalam mempertimbangkan keputusan yang diambil.

\subsection{Saran-saran}

Berdasarkan pada hasil dan kesimpulan penelitian ini, dapat dikemukakan saran-saran yang menjadi rekomendasi pada penelitian berikutnya.

1. Diharapkan penelitian mendatang tidak hanya melihat mental accounting saja, karena masih ada $p s y c h o l o g i c a l$ bias yang lain mungkin saja juga berpengaruh dalam keputusan investasi dan kinerja perusahaan, seperti: representativeness, availability dan conservatism.

2. Penelitian yang akan datang diharapkan sampel penelitian tidak hanya terbatas pada UKM gerabah yang ekspor saja, karena masih banyak UKM ekspor yang berkembang di masyarakat, seperti UKM kerajinan bambu dan kayu. 
3. Penelitian yang akan datang diharapkan mengkaji secara mendalam penyebab pengelola UKM belum bisa mengelola keuangan dengan baik, walaupun sudah mendapatkan pelatihan yang berkaitan dengan pengelolaan keuangan.

4. Penelitian yang akan datang, diharapkan tidak saja pada profit organization tapi juga pada non profit organization, aparat pemerintah dan rumah tangga, sehingga bisa diketahui bagaimana keuangan perilaku pada objek penelitian yang lain.

\section{DAFTAR PUSTAKA}

Asri, Marwan. 2013. Keuangan Keperilakuan. Edisi Pertama. BPFE-UGM. Yogyakarta.

Baptista, Alexandre M. 2012. Portfolio selection with mental accounting and background risk. Journal of banking \& Finance, vol. 36, pp.968-980

Bell, D. 1992. Regret in Decision Making Under Uncertainty. Operation Research, 30 (5), pp. 961-981

Caballero, Sonia Banos; Teruel, Pedro J. Garcia and Solano, Pedro Martinez. 2011. Working Capital Management, Corporate Performance, and Financial Constraint. Dep. Management and Finance, Faculty of Economics and Business, University of Murcia, Murcia (SPAIN).

De Bondt, W. et al. 2008. Behavioral Finance: Quo Vadis ?. Journal of Applied Finance; Fall 2008; 18, 2; $\mathrm{ABI} / \mathrm{INFORM}$ Research.

Eichholtz and Yonder. 2011. CEO Overconfidence, Corporate Investment Activity, and Performance: Evidence from REITs. Working Paper. Faculty of Business and Economics. Maastricht University Netherlands.

Ferdinand, Augusty. 2011. Metode Penelitian Manajemen. BP. UNDIP. Semarang

Forbes, William.2009. Behavioural Finance. First Edition. John Wiley \& Sons Ltd.

Gumanti, Ary Tatang. 2009, Behavior Finance: Suatu Telaah. Usahawan No. 1/Th, XXXVIII.

Hayajneh and Yassine. 2011. The Impact of Working Capital Efficiency on Profitability-an Empirical Analysis on Jordanian Manufacturing Firm, International Research Journal of Finance and Economics, ISSN 1450-2887 Issue 66.

Helliar. Power and Sinclair.1. 2005. Manager "Irrationallty" in financing Decision Making. Managerial Finance. Vol. 3, Number 4.

Idrus, M. Syafiie. 1999. Strategi Pengembangan Kewirausahaan (Entreprenuership) dan Peranan Perguruan Tinggi dalam Rangka Membangun Keunggulan Bersaing (Competitive Advantage) Bangsa Indonesia pada Millenium Ketiga, Makalah tidak dipubilkasikan, Universitas Brawijaya.

Iramani dan Bagus, Dhyka. 2008. Faktor-faktor Penentu Perilaku Investor dalam transaksi Saham di Surabaya. Jurnal Aplikasi Manajemen, Vol. 6, No. 3.

Lintner, G. 1998. Behavioral Finance: Why Investors Make Bad Decisions. The Planner, 13 (1), 7-8. Vol. 68, No.4, pp. 748-764.

Lipe.1993. Analyzing the Variance Investigation decision: The Effect of Outcomes, Mental Accounting, and Framing. The Accounting Review. Vol. 68, No.4, pp.748-764.

Notoatmodjo, Soekidjo. 2003. Pengembangan Sumber Daya Manusia. Rineka Cipta. Jakarta.

Nyamao; Patrick; Martin; Odondo and Simeyo. (2012). Effect of working capital management practices on financial performance: A study of small scale enterprises in Kisii South District, Kenya. African Journal of Business Management, Vol. 6, pp. 5807-5817.

Pompian, Michael M.2006. Behavioral Finance and Wealth Management. John Wiley \& Sons, Inc. 
Prakoso, N. Iman. 2009. Permasalahan Mental Accounting dan Kepatuhan terhadap Syariah Islam dalam Keputusan Pendanaan: Sebuah Eksperimen. Journal of Islamic Business and Economics, Juni 2009, Vol. 1, No. 3, pp. 127-159

Ramiah; Zhao; Graham and Moosa. 2012. Behavioural Aspects of Working Capital Managers. School of Economics, Finance and Marketing, RMIT University, Australia.

Rockenbach, Bettina. 2002. The Behavioral Relevance of Mental Accounting for the Pricing of Financial Option. Journal of Economic Behavior \& Organization, Vol.53, pp. 513-527.

Sekaran, Uma. 2009. Metode Penelitian untuk Bisnis. Buku 1. Edisi 4. Salemba Raya. Jakarta

Supramono; Kaudin; Mahastuti dan Damayanti. 2010. Desain Penelitian Keuangan Berbasis Perilaku. Penerbit: Pusat Studi Keuangan Berbasis Perilaku Fakultas Ekonomi UKSW Salatiga

Sugiyono. 2008. Metode Penelitian Bisnis (Pendekatan Kuantitatif, Kualitatif dan R \& D). CV. Alfabeta. Bandung

Solimun. 2012. Pemodelan Persamaan Struktural: Generalized Structured Component Analysis GSCA. Materi Pelatihan Statistic Multivariat. Fakultas MIPA. Universitas Brawijaya.

Thaler, R. 1999. Advances in Behavioral Finance. New York. Russel Sage Foundation.

Trinugroho, dan Sembel. 2011. Overconfidence and Excessive Trading Behavior: An Experimental Study. International Journal of Business and Management, Vol. 6, No. 7.

Tversky, A, and Brack, Davis.1995. The Psychology of Decision Making. Behavioral Finance and Decision Theory in Investment Management. AIMR. Charlottesville.USA

Vos, Yeh, Carter and Tagg. 2007. The happy story of small business financing. Journal of Banking and Finance, Vol. 31, pp. 2648-2672.

Weston, J. Fred and Copeland, Thomas E. 1986. Managerial Finance. CBS International Edition. CBS College Publishing. New York.

Widyastuti, Arie. Behavioral Finance dalam Proses Pengambilan Keputusan. Makalah Dipresentasikan di LMFE UNPAD. www. Unpad ac.id.Januari 2012

http://www.Diskop.Padang.go.id. September 2015

http://www.ekonomi.kompasiana.com/moneter/2012/03/15/psikologi-keuangan-1. September 2015 